University of Nebraska - Lincoln

DigitalCommons@University of Nebraska - Lincoln

USDA National Wildlife Research Center - Staff Publications
U.S. Department of Agriculture: Animal and Plant Health Inspection Service

2009

\title{
Evaluation of Attractants to Improve Trapping Success of Nutria on Louisiana Coastal Marsh
}

\author{
Susan Jojola \\ USDA-APHIS-Wildlife Services
}

Gary W. Witmer

USDA-APHIS-Wildlife Services, gary.w.witmer@usda.gov

Patrick Burke

USDA-APHIS-Wildlife Services

Follow this and additional works at: https://digitalcommons.unl.edu/icwdm_usdanwrc

Part of the Environmental Sciences Commons

Jojola, Susan; Witmer, Gary W.; and Burke, Patrick, "Evaluation of Attractants to Improve Trapping Success of Nutria on Louisiana Coastal Marsh" (2009). USDA National Wildlife Research Center - Staff

Publications. 929.

https://digitalcommons.unl.edu/icwdm_usdanwrc/929

This Article is brought to you for free and open access by the U.S. Department of Agriculture: Animal and Plant Health Inspection Service at DigitalCommons@University of Nebraska - Lincoln. It has been accepted for inclusion in USDA National Wildlife Research Center - Staff Publications by an authorized administrator of DigitalCommons@University of Nebraska - Lincoln. 


\title{
Evaluation of Attractants to Improve Trapping Success of Nutria on Louisiana Coastal Marsh
}

\author{
SUSAN M. JOJOLA, United States Department of Agriculture, Animal and Plant Health Inspection Service, Wildlife Services, National Wildife Research \\ Center, 4101 LaPorte Avenue, Fort Collins, CO 80521-2154, USA \\ GARY W. WITMER, ${ }^{1}$ United States Department of Agriculture, Animal and Plant Health Inspection Service, Wildlife Services, National Wildife \\ Research Center, 4101 LaPorte Avenue, Fort Collins, CO 80521-2154, USA \\ PATRICK W. BURKE, United States Department of Agriculture, Animal and Plant Health Inspection Service, Wildlife Services, National Wildlife \\ Research Center, 4101 LaPorte Avenue, Fort Collins, CO 80521-2154, USA
}

\begin{abstract}
Nutria (Myocastor coypus) are an important part of the Louisiana (USA) fur industry, but high densities of nutria cause extensive damage to coastal marsh ecosystems. Hence, there is a need to develop improved methods for targeted management of nutria. We screened 14 olfactory cues as potential lures for nutria, first in controlled settings and then in the field, to see if nutria capture rates using foothold traps would increase. In Y-maze trials, nutria most frequently selected olfactory cues of a synthetic formulation of nutria anal-gland secretion and nutria fur extract. We examined the 3 most selected attractants in Y-maze trials and female nutria urine under field conditions to compare trapping success over untreated traps. Capture probability was nearly 2.5 times greater for fur wash than control and 2 times greater for urine than control (relative risk $=2.43$ and 2.01, respectively). The results suggest that use of semiochemicals and synthetic formulations of semiochemicals increased nutria trapping success. Development and use of effective synthetic semiochemicals could benefit resource managers nationwide who are responsible for reducing damage caused by this invasive herbivore. (JOURNAL OF WILDLIFE MANAGEMENT 73(8):1414-1419; 2009)
\end{abstract}

DOI: $10.2193 / 2008-106$

KEY WORDS attractants, capture rate, control, damage management, Louisiana, lures, Myocastor coypus, nutria, semiochemical, trapping.

Nutria (Myocastor coypus) are large semi-aquatic rodents native to South America. During the 1930s, fur farms in 7 United States, including Louisiana, imported nutria (Kinler et al. 1987). Since then, accidental and intentional releases have resulted in wide distribution of the species (Carter and Leonard 2002). By the mid-1950s the nutria population in Louisiana reached an estimated 20 million animals and reports of damage to marshes, agriculture, and levee systems were common (Louisiana Department of Wildlife and Fisheries [LDWF] 2007). Fortunately, a steady increase in the value of nutria fur between 1960 and 1980 resulted in an average annual harvest in Louisiana of 1.3 million nutria (Scarborough and Mouton 2007), and reports of nutria damage declined (LDWF 2007). When the international fur market began to decline in the mid1980s, resulting in reduced harvest levels of nutria in Louisiana, reports of nutria damage again became common. The decline of the fur market and in nutria pelt values from 1980 to 2000 invoked resource managers to seek other markets for nutria, including human consumption of the meat, to maintain hunting and trapping pressure responsible for mitigating damage to agriculture and wetlands caused by nutria.

In Louisiana, nutria provide recreational and commercial opportunities for hunters and trappers. Thus, statewide eradication of nutria is not an objective. However, local extirpation of nutria is desired in areas where high-density populations significantly damage natural resources. Although the eradication of nutria once well-established is very difficult

\footnotetext{
${ }^{1}$ E-mail: gary.w.witmer@aphis.usda.gov
}

and costly, nutria introduced to the United Kingdom were successfully eradicated after several years of intensive trapping (Gosling and Baker 1989). In 2002, the LDWF implemented the Coastwide Nutria Control Program (CNCP), an incentive-payment program during trapping season (NovMar), to encourage hunters and trappers to harvest nutria as a means to decrease damage caused by nutria. The program, analogous to a bounty program, offered US $\$ 4 /$ nutria tail (US\$5/tail in 2006-2007) to registered participants. In 20012002 , the trapping season before the program's inception, the nutria harvest remained low at 24,683 pelts. Five years later, the $\mathrm{CNCP}$ increased the nutria harvest to 375,683 pelts in 2006-2007 (Scarborough and Mouton 2007).

Wetlands support numerous aquatic and terrestrial species, abate storm impacts on infrastructure and communities, and provide the core habitat for the substantial hunting and fishing industry. Excessive nutria herbivory jeopardizes these benefits. The feeding patterns of nutria identify them as at least a contributing factor to the decline of native Louisiana coastal marsh (Shaffer et al. 1992, Grace and Ford 1996, Evers et al. 1998). A study in Chile observed that a nutria can consume approximately $25 \%$ of its individual body mass per day in vegetation (Christen 1978). Vegetation surveys in Louisiana in the 1990s identified nutria as the cause of damage to several tracts of marsh totaling over 100,000 acres (N. Kinler, Louisiana Department of Wildlife and Fisheries, unpublished report). After 5 years of the CNCP implementation, vegetation surveys showed that herbivory damage decreased from 32,150 ha in 2001-2002 to 14,028 ha in 2006-2007 (Scarborough and Mouton 2007). The CNCP is having a positive influence on the recovery of wetlands. 
Between 2002 and 2007, 39\% of nutria harvested under the CNCP in Louisiana were captured with foothold traps, $51 \%$ were harvested with a rifle, and $9.2 \%$ were taken with a shotgun (Scarborough and Mouton 2007). Development of effective lures for nutria may increase harvest with foothold traps. Effective lures would directly assist with mitigation of impacts in wetlands and agriculture by increasing the capture rate of nutria. Pen trials by Nolte et al. (2004) suggested that nutria were more attentive to olfactory cues than to visual or auditory cues. Our purpose was to screen olfactory cues for nutria and evaluate efficacy of scent lures for captures in foothold traps on Louisiana coastal marshes.

\section{STUDY AREA}

We conducted Y-maze and pen trials at the outdoor facilities of the LDWF in New Iberia, Louisiana. We conducted field trials in cooperation with a commercial trapping operation being carried out on and near the Mandalay National Wildlife Refuge, located in Terrebonne Parish, in southeast Louisiana. The 1,705-ha refuge was composed mostly of freshwater marsh with man-made canals and levees. The refuge was managed to provide habitat for waterfowl, wading birds, and neotropical songbirds. Access to the refuge was by boat only and foot travel was extremely difficult due to the soft, floating marsh environment dominated by maidencane (Panicum hemitomon) and bulltongue (Sagittaria lancifolia). Giant cut grass (Zizaniopsis miliacea) was also present and provided good hiding cover for nutria. A major landscape feature of the refuge was the levees created from the spoil resulting from canal construction. The levees provided linear strips of solid ground, which allowed for the growth of woody species, such as willow (Salix sp.), water oak (Quercus nigra), red maple (Acer rubrum), and wax myrtle (Myrica cerifera) trees. Nearby were large stands of bald cypress (Taxodium distichum).

\section{METHODS}

\section{Y-Maze Trials}

We screened 14 olfactory cues in a Y-maze (3.5-m stem and 1.8-m arms; Fig. 1) from 11 March to 17 March 2005. We ran a series of 2-choice trials in the Y-maze and randomly assigned the test material and distilled water to each arm. We dispensed 1 cubic centimeter (cc) of a test material or distilled water on filter paper in a shallow tin weigh pan and placed it at the end of an arm of the Y-maze. An exhaust fan mounted above the start box pulled air through the maze at $8.3 \mathrm{~m} /$ second. Our noses could detect the odor volatiles expelled from the maze by the fan. The observer placed individual nutria in the start box, then released them into the Y-maze by lifting a black, plastic drop door via a pulley system. The observer sat on an elevated platform within a blind near the fork of the Y-maze where the choice point (CP; Fig. 1) and selection points (SP) were visible by direct observation. We conducted trials at night using red lights because nutria are primarily nocturnal.

We categorized the 14 odors as 1) food flavors and fragrances, 2) commercial nutria lures, and 3) semiochemicals. Food flavors and fragrances included nutty, pineapple, coconut, sour cheese, and banana (Sigma-Aldrich, Milwaukee, WI). Commercial nutria lures included spearmint oil

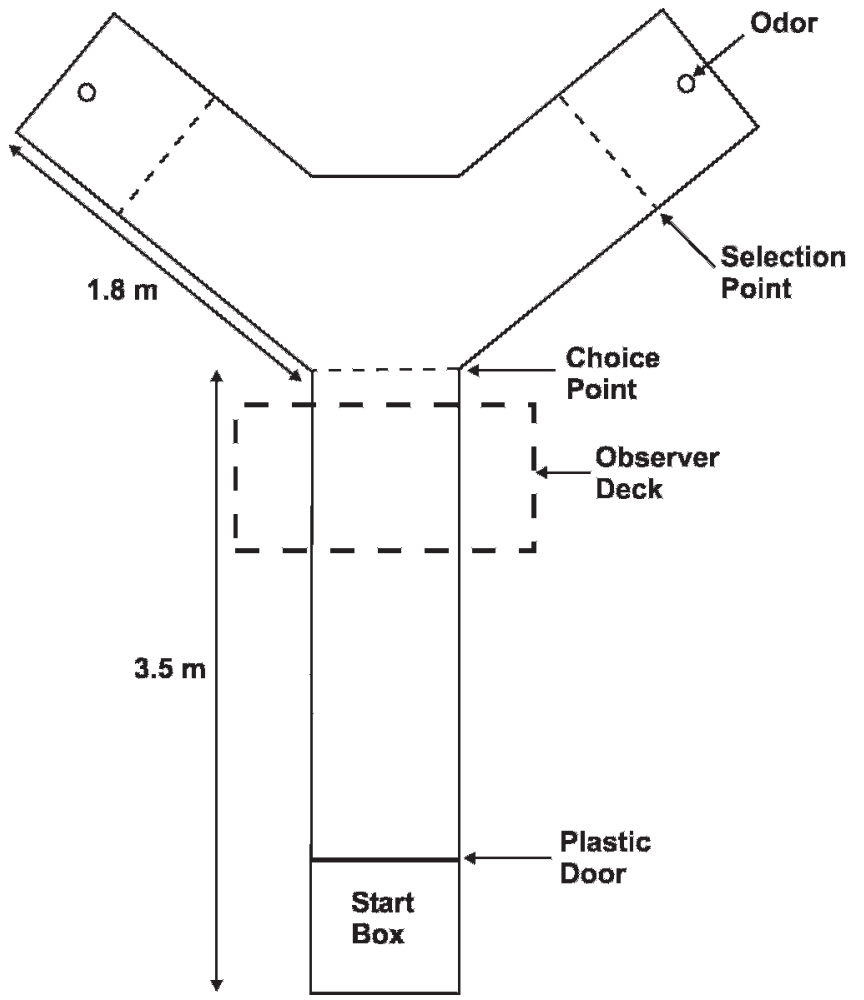

Figure 1. The enclosed $\mathrm{Y}$-maze we used to screen odor attractants for nutria in New Iberia, Louisiana, USA, 11-17 March 2005.

(Cumberland's Northwest Trappers Supply, Inc., Owatonna, MN), fatty acid scent (Pocatello Supply Depot, Pocatello, ID), and Tom's Nutria \#1 and Tom's Nutria \#2 (Lone Oak Trading Company, Salem, OR). Tom's Nutria \#1 and \#2 were apple-based, contained no animal products, used propylene glycol as a carrier and antifreeze agent, and were food scents (proprietary). The food scents in Nutria \#1 were different from those in Nutria \#2. The semiochemical group included synthetic formulations. Semiochemicals are chemical-releasing stimuli that an organism makes, bears, or both and that may, or actually does, influence the behavior of $\geq 1$ other organisms (Weldon 1980). Synthetic anal-gland secretion (AGS) and fur extract lures were AGS A, AGS B, AGS C, male fur extract, and female fur extract. Analgland secretion treatments were synthetic formulations based on a chemical profile analysis of an adult male's anal glands (Finckbeiner 2005, Lee et al. 2007). Anal-gland secretion B was a close mimic of the complete chemical profile at the time of the study; AGSs A and C were similar to B except one major component of the chemical profile was excluded from each. Fur extracts were formulated by a chemical washing of the fur to extract volatiles, using the organic solvent pentane (S. Finckbeiner, Cornell University, personal communication). We cut fur from recently harvested nutria using clean scissors. We placed the fur in a bottle and covered it with pentane. We left the solution in the bottle for several days with occasional stirring or shaking. Before use in trials, we transferred the solution to a clean bottle by pouring through Whatman filter paper (Whatman International, Ltd., Maidstone, United Kingdom). 
We locally captured 24 adult $(>4 \mathrm{~kg})$ nutria and divided them into 3 groups of 8 with equal numbers of each sex per group. We exposed each of the 8 animals within a group only once to each odor within an assigned odor group (food flavors and fragrances, commercial nutria lures, or semiochemicals). We fed captive nutria sweet potatoes, carrots, and a commercial rodent chow (Teklad Rodent Diet, Harlan Teklad, Madison, WI), and did not food-deprive the animals prior to trials. We acclimated animals to the $\mathrm{Y}-$ maze enclosure prior to trials by leaving groups of nutria in the maze overnight. We recorded which SP nutria reached during an individual run. If a nutria did not reach a SP after 5 minutes, we terminated the trial run and recorded it as "no selection." In our opinion, this provided a reasonable preliminary model of a field situation in which a runwaybound animal was expected to deviate from its path after detecting a favorable odor stream (i.e., the test lure). We washed the Y-maze with a dilute bleach solution (1:100 bleach:water) after each run and allowed it to air-dry before beginning a new run.

We ran Fisher exact tests on treatment $\times$ choice contingency tables for each of the 3 odor groups to determine if there was significance in selections of treatment odors, water, or no selections. We used descriptive bar graphs to display male and female selections of olfactory cues.

\section{Field Trials}

We applied olfactory lures identified as attractive to nutria in the Y-maze trials near foothold traps to test for increased capture rates. We also used female nutria urine because urine is a common odor cue for many mammals in the wild (Miller et al. 1998, Young and Henke 1999, Roberts et al. 2001, Beynon and Hurst 2004). We placed urine from the bladders of recently harvested female nutria into bottles for use in the lure trial. We applied lures by spraying or pouring approximately $1 \mathrm{cc}$ about $0.25 \mathrm{~m}$ behind the trap, which was placed at the discretion of a commercial trapper, but always about $0.3 \mathrm{~m}$ from a nutria runway. We never placed treatment or control traps directly in a nutria trail, which is the normal placement by commercial trappers. We did this to test the attractant quality of the lures rather than quantify inadvertent captures of nutria traveling on the trail. We re-applied treatments to traps every other day. We ran field trials between 23 January and 2 February 2006.

We used 100 Number 1.5 foothold traps for the field study. We set traps for 10 nights; we set traps in one location (area 1) for 5 consecutive nights then moved them to a new location (area 2) for the next 5 nights. We placed traps in 2 habitat types, on floating marsh mats and on nearby levees, in nearly equal proportion. We used a repeated block design whereby the 4 odor treatments or the control (water only) were each randomly assigned to 4 traps in the first group of 20 traps. We repeated this pattern on the remaining 4 blocks of 20 traps $(n=20$ traps/odor treatment, $n=20$ traps control). We treated traps in the control group only with water, and we monitored as per treated traps. We placed each trap $\geq 10 \mathrm{~m}$ from any other trap to avoid the confounding effect of $>1$ lure odor occurring near a trap.
We gave each trap a unique number inscribed on a plastic flag attached to a 2-m stake that we used to anchor the trap via a chain. The commercial trapper set traps and traplines and maintained them as closely as possible to the normal routine of a commercial trapping operation. We monitored traps daily and recorded captures by date, trap number, and treatment. If a trap caught a nutria, we then reset the trap and re-treated it with the appropriate lure. We euthanized all nutria collected. We recorded sex and weight of each nutria captured and categorized each animal as an adult or a juvenile-subadult based on weight and pelage characteristics (Brown 1975). We counted escaped animals as captures and included them in data tabulations if we could confirm sign in the trap, such as toenails, fur, or whiskers, as nutria. We recorded nontarget captures and, when possible, immediately released them on-site. If release was not possible and the animal was still alive, we euthanized nontarget animals.

We modeled capture probability as a function of fixedeffects area, habitat, attractant, and all interactions, assuming binomial distribution and logit link using PROC GLIMMIX (SAS Institute, Inc., Cary, NC). Experimental units were trap locations nested within area $X$ habitat $X$ attractant cells. To account for effects of repeated measures (i.e., nights) within experimental units, we evaluated models using residual covariance structures including unstructured (Cholesky root), Toeplitz, first-order autoregressive, and compound symmetry. We used Toeplitz covariances for parameter estimation because they appeared to best fit the decreasing trend in unstructured covariances with increasing temporal distance from the first trap-night. We also evaluated a combination of compound symmetry and firstorder autoregressive structures to model both random effects of trap location and residual correlation. We selected a covariance structure for estimation using graphical evaluation (Littell et al. 2006). We estimated relative risk (RR) to compare estimated capture rates of attractants $\left(\mathrm{p}_{\mathrm{a}}\right)$ to control $\left(\mathrm{p}_{\mathrm{c}}\right)$, as $\mathrm{RR}=\mathrm{p}_{\mathrm{a}} / \mathrm{p}_{\mathrm{c}}$, substituting degrees of freedom from the model in place of sample size (Agresti 1996). Estimates of $\mathrm{RR}>1$ (i.e., lower $95 \% \mathrm{CI}>1$ ) indicated improved performance of attractants relative to control.

We conducted the study in accordance with Animal Welfare Act regulations and the United States Department of Agriculture, Animal and Plant Health Inspection Service, Wildlife Services, National Wildlife Research Center's Institutional Animal Care and Use Committee approved the study protocols (QA-1252, QA-1284).

\section{RESULTS}

The 8 nutria in the food flavors and fragrances group made no selection $70 \%$ of the time (Fig. 2). There were no differences in treatment selections, water selections, or no selections $(P=0.60)$. Due to the low response by nutria in this group, we did not examine these odors in subsequent field trials. The 8 nutria in the commercial nutria lure group made no selection $50 \%$ of the time (Fig. 2). There were no differences in treatment selections, water selections, or no selections $(P=0.73)$. However, nutria selected all commercial lures at least once; Nutria \#1 was selected 4 


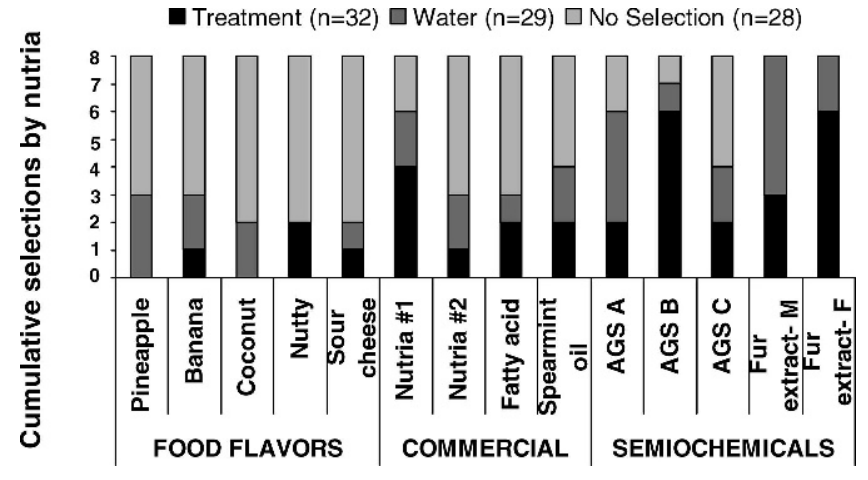

Figure 2. Cumulative selections by nutria for the treatment odor, water, or neither in Y-maze trials in New Iberia, Louisiana, USA, 11-17 March 2005. We exposed 8 nutria/odor group $(N=24)$ once to each odor within an odor group. AGS = anal-gland secretion.

times (Fig. 2). The 8 nutria in the semiochemical group made no selection only $17.5 \%$ of the time (Fig. 2). There were no differences in treatment selections, water selections, or no selections $(P=0.06)$. Nutria selected anal-gland secretion B and female fur extract 6 times each (Fig. 2). The 3 most-selected odors in Y-maze trials were AGS B, Nutria $\# 1$, and female fur extract, and we tested these in the field.

Of the 285 nutria we captured in the field (Table 1; Fig. 3), 81 escaped the traps (Table 1; Fig. 3). All lures increased trapping success $\geq 2$-fold over untreated traps. Capture rate was strongly associated with attractant $(P=$ $0.001)$ but not with interactions involving attractant $(P \geq$ 0.114; Table 2). Thus, regardless of habitat type or area, the lures by themselves were what influenced capture. Capture probability was nearly 2.5 times greater for fur wash than control and 2 times greater for urine than control $(\mathrm{RR}=$ 2.43 and 2.01, respectively; Table 3). The capture probabilities for AGS B and Tom's Nutria \#1 were only about 1.5 times greater than control $(\mathrm{RR}=1.55$ and 1.60, respectively). Nutria captures also varied by area, with 29 more captures $(P=0.046)$ in area 1 than in area 2 , and by habitat type, with 35 more captures $(P=0.008)$ in marsh habitat than levee habitat (Table 1).

Of the 204 captured nutria that we could sex, 115 (56.4\%) were males and $89(43.6 \%)$ were females. The average weight for male nutria captured was $3.83 \mathrm{~kg}(\mathrm{SD}=1.82 \mathrm{~kg})$. The smallest male captured was $1.0 \mathrm{~kg}$ and the largest was $7.0 \mathrm{~kg}$. Average weight for female nutria captured was $4.05 \mathrm{~kg}$ (SD = $1.43 \mathrm{~kg}$ ). The range for female nutria weights was $1.0-6.5 \mathrm{~kg}$. Overall average weight for all captured nutria was $3.92 \mathrm{~kg}$ (SD $=1.67 \mathrm{~kg}$ ). Of captured nutria, we classified $83.3 \%$ as adults and $16.7 \%$ as juveniles-subadults.

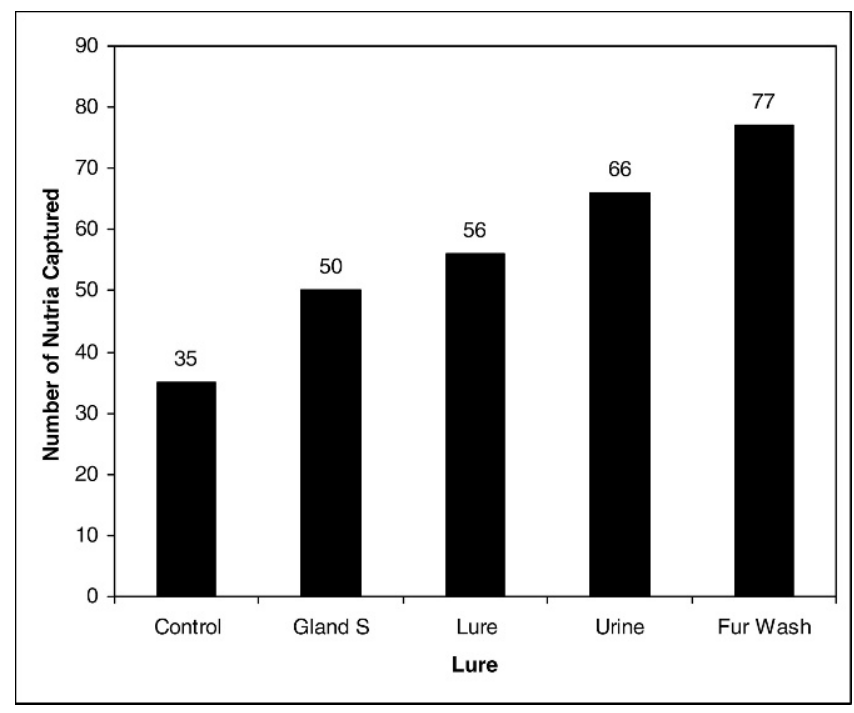

Figure 3. Nutria captures by attractant type in 1,000 trap-nights (200 trap-nights/lure type) using leg-hold traps on and near the Mandalay National Wildlife Refuge in southern Louisiana, USA, 23 January-2 February 2006.

We captured only 15 nontarget animals during 1,000 trapnights. This represents a low nontarget capture rate of $1.5 \%$. We captured 6 wading birds, 5 swamp rabbits (Sylvilagus aquaticus), 2 alligators (Alligator mississippiensis), one red-tailed hawk (Buteo jamaicensis), and one raccoon (Procyon lotor); most were uninjured and immediately released. We captured more nontarget animals in marsh trap sets $(n=10)$ than in levee trap sets $(n=5)$. We captured nontarget animals in traps scented with all attractants as well as in control traps.

\section{DISCUSSION}

Nutria semiochemicals were most attractive to nutria in the Y-maze trial. The field trial emphasized that lures we tested were indeed attractive to wild nutria and that nutria were willing to investigate the lures in a natural setting. In particular, using female fur wash and female urine greatly increased capture rates. We captured males and females in similar numbers, and nutria of a wide range of sizes. We did catch fewer juvenile-subadult nutria than adult nutria, maybe because there are few nutria of the younger age classes in populations at the time of year of the study (JanFeb) because of greatly reduced reproduction in the autumn (Bounds et al. 2003). It may also be because young nutria were following adults rather than leading their own way through the marsh. It is likely that capture rates of all nutria may have been greater than we observed if traps had been

Table 1. Trap-nights and nutria captures ${ }^{a}$ by study area and by habitat type in field trials to evaluate attractants for nutria on and near the Mandalay National Wildlife Refuge in southern Louisiana, USA, 23 January-2 February 2006.

\begin{tabular}{|c|c|c|c|c|c|c|}
\hline \multirow[b]{2}{*}{ Habitat } & \multicolumn{2}{|c|}{ Area 1} & \multicolumn{2}{|c|}{ Area 2} & \multicolumn{2}{|c|}{ Both areas } \\
\hline & Trap-nights & Captures & Trap-nights & Captures & Trap-nights & Captures \\
\hline Levee & 270 & 68 & 235 & 57 & 505 & 125 \\
\hline Marsh & 230 & 89 & 265 & 71 & 495 & 160 \\
\hline Both habitats & 500 & 157 & 500 & 128 & 1,000 & 285 \\
\hline
\end{tabular}

\footnotetext{
${ }^{a}$ Nutria captures includes escape events that could be attributed to nutria.
} 
Table 2. Type III tests of fixed effects for the statistical analysis of the field trial evaluating attractants for nutria on and near the Mandalay National Wildlife Refuge in southern Louisiana, USA, 23 January-2 February 2006.

\begin{tabular}{lccc}
\hline \multicolumn{1}{c}{ Effect } & df & $\boldsymbol{F}$ & $\boldsymbol{P}$ \\
\hline Area & 1 & 4.03 & 0.046 \\
Habitat & 1 & 7.02 & 0.009 \\
Area $\times$ habitat & 1 & 1.02 & 0.315 \\
Attractant & 4 & 4.66 & 0.001 \\
Area $\times$ attractant & 4 & 1.89 & 0.114 \\
Habitat $\times$ attractant & 4 & 0.38 & 0.824 \\
Area $\times$ habitat $\times$ attractant & 4 & 0.40 & 0.809 \\
\hline
\end{tabular}

placed in nutria trails as normally practiced by trappers. Capture rates were greater in area 1 than in area 2, which may have resulted from a greater density of nutria in area 1. We did not attempt to estimate nutria densities in the study area, however, primarily because accurate estimators for nutria do not exist (Bounds et al. 2003). Capture rates also were greater with trap sets on marsh habitat versus levee habitat, possibly because nutria are actively foraging when on floating marsh vegetation; nutria are more likely to be resting or in burrows when at levee sites. This field study revealed that nontarget captures using these nutria lures were much fewer than captures of the targeted nutria, which is an important characteristic of any lure intended to be used in a natural setting.

\section{MANAGEMENT IMPLICATIONS}

Lure and attractant evaluation is part of a larger effort to improve animal capture, visitation, or uptake of treatments. That 2 of the lures we tested more than doubled the capture probability over control traps suggests that semiochemicals would be an effective tool to help manage nutria populations. It is also important that we lured both sexes and an array of sizes of nutria to the treated traps and we captured few nontarget animals. We argue that development and evaluation of semiochemicals for operational use by managers and trappers is the next logical step in attractant research and targeted management, especially in the case of nutria. Often, acquiring biological material from animals is a limiting factor in research and development, but this might not be the case with nutria, which are harvested in the hundreds of thousands per year. Sample collection could be

Table 3. Estimated capture probabilities and relative risk for nutria attractants applied to leg-hold traps set on and near the Mandalay National Wildlife Refuge in southern Louisiana, USA, 23 January-2 February 2006.

\begin{tabular}{|c|c|c|c|c|}
\hline \multirow[b]{2}{*}{ Attractant } & \multicolumn{2}{|c|}{ Capture probability } & \multicolumn{2}{|c|}{ Relative risk ${ }^{a}$} \\
\hline & Estimate & $95 \% \mathrm{CI}$ & Estimate & 95\% CI \\
\hline Control (no lure) & 0.159 & $0.104-0.234$ & & \\
\hline$F$ fur wash & 0.386 & $0.309-0.470$ & 2.43 & $1.65-3.57$ \\
\hline $\begin{array}{l}\text { Anal-gland } \\
\text { secretion B }\end{array}$ & 0.246 & $0.182-0.325$ & 1.55 & $1.01-2.37$ \\
\hline Nutria \#1 & 0.255 & $0.186-0.338$ & 1.60 & $1.05-2.44$ \\
\hline F urine & 0.319 & $0.247-0.401$ & 2.01 & $1.34-2.99$ \\
\hline
\end{tabular}

${ }^{a}$ Ratio of (capture probability of the attractant)/(capture probability of the control). managed at Coastwide Nutria Control Program stations. When these semiochemicals or synthetic formulations of them are further refined and made available for widespread use, commercial and recreational trappers may be able to increase their harvest of nutria, which would help land managers nationwide mitigate damages to natural resources inflicted by this invasive, aquatic herbivore.

\section{ACKNOWLEDGMENTS}

A. Dolan, United States Fish and Wildlife Service, provided funds for the study. G. Linscombe (retired), E. Mouton, and staff at the Louisiana Department of Wildlife and Fisheries provided advice, facilities, labor, and other in-kind support. D. LeBlanc of Wildlife Services, Louisiana, provided in-kind support and technical and field assistance. D. Nolte, Wildlife Services-National Water Research Center (NWRC), initiated the nutria lure studies. P. Yakupzack and B. Fortier, Mandalay National Wildlife Refuge, provided in-kind support and refuge access. V. Naquin provided trapping equipment and expertise. D. Leget allowed access to his property and equipment. J. Leger, Wildlife Services, Louisiana, cared for study animals, implemented research trials, and viewed video film. S. Kendrot, Wildlife Services, Maryland, provided some test materials and information. S. Rizor and K. Perry, Wildlife Services, NWRC, Washington, helped with nutria handling and video systems. G. Phillips and B. Kimball, Wildlife Services, NWRC, Colorado, assisted with statistical analyses. C. Autran, J. Grove, R. Piergross, and M. Marcelin, Colorado State University students, assisted with parts of the studies. Mention of companies or commercial products does not imply recommendation or endorsement by the United States Department of Agriculture. Product names are mentioned solely to report factually on available data and to provide specific information.

\section{LITERATURE CITED}

Agresti, A. 1996. An introduction to categorical data analysis. John Wiley and Sons, New York, New York, USA.

Beynon, R. J., and J. L. Hurst. 2004. Urinary proteins and the modulation of chemical scents in mice and rats. Peptides 25:1553-1563.

Bounds, D. L., M. H. Sherfy, and T. A. Mollett. 2003. Nutria. Pages 1119-1147 in G. A. Feldhamer, B. C. Thompson, and J. A. Chapman, editors. Wild mammals of North America: biology, management, and conservation. The Johns Hopkins University Press, Baltimore, Maryland, USA.

Brown, L. N. 1975. Ecological relationships and breeding biology of the nutria (Myocastor coypus) in the Tampa, Florida, area. Journal of Mammalogy 56:928-930.

Carter, J., and B. P. Leonard. 2002. A review of the literature on the worldwide distribution, spread of, and efforts to eradicate the coypu (Myocastor coypus). Wildlife Society Bulletin 30:162-175.

Christen, M. F. 1978. Evalución nutritive de cuatro dietas monoespecificas en la alimentación del coipo (Myocastor coypus). Tesis Faculitad de Medicina Veterinaria, Universidad Austral de Chile, Valdivia, Chile. [In Spanish.]

Evers, D. E., C. E. Sasser, J. G. Gosselink, D. A. Fuller, and J. M. Visser. 1998. The impact of vertebrate herbivores on wetland vegetation in Atchafalaya Bay, Louisiana, USA. Estuaries 21:1-13.

Finckbeiner, S. M. 2005. Partial characterization of coypu scent gland compounds and a new technique for computer-aided photographic identification of individual coypu. Thesis, Cornell University, Ithaca, New York, USA. 
Gosling, L. M., and S. J. Baker. 1989. The eradication of muskrats and coypus from Britain. Biological Journal of the Linnean Society 38:39-51.

Grace, J. B., and M. A. Ford. 1996. The potential impact of herbivores on the susceptibility of the marsh plant Sagittaria lancifolia to saltwater intrusion in coastal wetlands. Estuaries 19:13-20.

Kinler, N. W., G. Linscombe, and P. R. Ramsey. 1987. Nutria. Pages 327342 in M. Novak, J. A. Baker, M. E. Obbard, and B. Malloch, editors. Wild furbearer management and conservation in North America. Ministry of Natural Resources, Toronto, Ontario, Canada.

Lee, H., S. Finckbeiner, J. S. Yu, D. F. Wiemer, T. Eisner, and A. B. Attygalle. 2007. Characterization of (E, E-) farnesol and its fatty acid esters from anal scent glands of nutria (Myocastor coypus) by gas chromatography-mass spectrometry and gas chromatography-infrared spectrometry. Journal of Chromatography A 1165:136-143.

Littell, R. C., G. A. Milliken, W. W. Stroup, R. D. Wolfinger, and O. Schabenberger. 2006. SAS System for mixed models. Second edition. SAS Institute, Cary, North Carolina, USA.

Louisiana Department of Wildlife and Fisheries [LDWF]. 2007. 20042005 annual report. Louisiana Fur and Alligator Advisory Council. Louisiana Department of Wildlife and Fisheries, New Iberia, USA.

Miller, K. V., B. Jemiolo, J. W. Gassett, I. Jelinek, D. Wiesler, and M. Novotny. 1998. Putative chemical signals from white-tailed deer
(Odocoileus virginianus): social and seasonal effects on urinary volatile excretion in males. Journal of Chemical Ecology 24:673-683.

Nolte, D. L., A. E. Barras, S. E. Adams, R. G. Linscombe, and D. J. LeBlanc. 2004. Assessing potential for using zinc phosphide bait to control nutria on Louisiana coastal marsh. Proceedings of the Vertebrate Pest Conference 21:150-157.

Roberts, S. C., L. M. Gosling, E. A. Thornton, and J. McClung. 2001. Scent-marking by male mice under the risk of predation. Behavioral Ecology 12:698-705.

Scarborough, J., and E. Mouton. 2007. Nutria harvest distribution 20062007 and a survey of nutria herbivory damage in coastal Louisiana in 2007. Fur and Refuge Division, Louisiana Department of Wildlife and Fisheries, New Iberia, USA.

Shaffer, G. P., C. E. Sasser, J. G. Gosselink, and M. Rejánek. 1992. Vegetation dynamics in the emerging Atchafalaya Delta, Louisiana. Journal of Ecology 80:677-687.

Weldon, P. J. 1980. In defense of "kairomone" as a class of chemical releasing stimuli. Journal of Chemical Ecology 6:719-725.

Young, J. G., and S. E. Henke. 1999. Effect of domestic rabbit urine on trap response in cottontail rabbits. Wildlife Society Bulletin 27:306-309.

Associate Editor: Mason. 